\title{
A detrital zircon LA-Q-ICPMS U-Pb study of upper schists from Vila Nune Unit, northern Portugal
}

\author{
R.J.S. TEIXEIRA ${ }^{1,2 *}$, S.C.C. GOMES ${ }^{3}$, M.E.P. GOMES ${ }^{1,2}$, \\ C. COKE ${ }^{1}$ AND A.J.C.M. PEREIRA ${ }^{1}$ \\ ${ }^{1}$ Department of Geology, University of Trás-os-Montes e \\ Alto Douro, Vila Real, Portugal (*rteixeir@utad.pt, \\ mgomes@utad.pt,ccoke@sapo.pt, ajmiranda@utad.pt) \\ ${ }^{2}$ Geosciences Centre, University of Coimbra, Portugal \\ ${ }^{3}$ Group of Schools of Sande, Marco de Canaveses, Portugal \\ (sibgo33@hotmail.com)
}

At Mondim de Basto region, an allochthonous nappe (Vila Nune Unit) was thrust over the parauthocthonous from the Galicia-Trás-os-Montes Zone. This unit consists, from bottom to top, of: a) micaceous and compact quartzites; b) intermediate-basic volcanites; c) acid volcanic tuffs; d) upper schists, with alternations of metapsammites. A preliminary LA-Q-ICPMS U-Pb study indicates that detrital zircons from the upper schists are dominated by Paleoproterozoic (40.4\%) and Neoproterozoic (38.5\%) ages, but Archean (13.4\%), Mesoproterozoic (3.8\%) and Ordovician/Silurian (3.8\%) ages also occur. Furthermore, the Vila Nune Unit hosts a Variscan granite (Paradança pluton) that contain inherited zircon cores with ages similar to those of the detrital zircons from upper schists. This fact is consistent with the $\mathrm{Sr}-\mathrm{Nd}$ isotopic affinity between that magma and correlative metapelites from Lower Allochthonous Thrust Complex of Morais Massif and, in a lesser extent way, to the underlain autochthonous metasediments from Douro Group (Central Iberian Zone), suggesting a derivation by partial melting of similar supracrustal rocks.

The age record suggests that the Vila Nune Unit's basin was located near or at the northern Gondwana margin, being filled by detritus of an inland Pan-African suture (858 - 855 $\mathrm{Ma})$ and a Cadomian magmatic arc $(663$ - $566 \mathrm{Ma})$. Furthermore, the Archean (2980 - 2530 Ma) and Paleoproterozoic (2357 - 1658 Ma) ages confirm a paleoposition in the proximity of the West African Craton. However, the contribution of other sources containing Mesoproterozoic and Tonian ages must also be considered. The occurrence of Ordovician/Silurian detrital and xenocrystic zircons $(481-410 \mathrm{Ma})$ is most probably related to the long-lived rift-stage Cambrian-Ordovician magmatism recognized in Iberian Massif, as well as in the West African Craton. The data set suggest a maximum depositional age for the upper schists ranging between 481 and $430 \mathrm{Ma}$. However, further detailed work is needed to refine this age, as well as those of the volcanites intercalated in the Vila Nune Unit. 